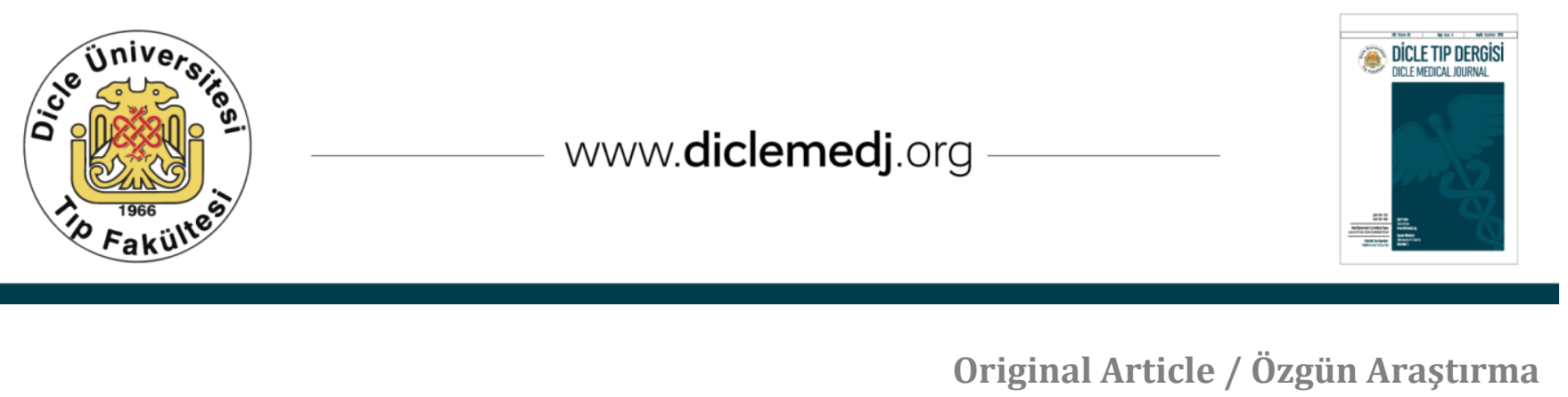

\title{
Neonatal hearing test results in the Çukurova region
}

\author{
Sanem Oksan Erkan ${ }^{1}$, Birgul Tuhanioğlu ${ }^{1}$ \\ 1 Dept of Otorhinolaryngology, Head and Neck Surgery; University of Health and Science, Adana City Training and Research Hospital, Adana, Turkey \\ ORCID: 0000-0001-5900-520X \\ 2 Dept of Otorhinolaryngology, Head and Neck Surgery; University of Health and Science, Adana City Training and Research Hospital, Adana, Turkey \\ ORCID: 0000-0002-8596-361X
}

Received: 13.03.2019; Revised: 02.07.2019; Accepted: 12.07.2019

\begin{abstract}
Objective: In this article, we aimed to present the neonatal hearing screening protocol and test results in healthy neonates in Adana City Training and Research Hospital, Adana.

Method: A total of 2022 healthy newborns were scanned between November 2018 and February 2019 in our hospital with a three-stage screening protocol. Initial transient evoked otoacoustic emissions (TEOAE), followed by a second stage transient evoked otoacoustic emission and third stage automated auditory brainstem response (A-ABR) were used. If there was a referral with these two methods, clinical BERA was used. High risk newborns were defined.

Results: In total, of the 2022 infants included in the study, hearing loss was detected in 34 newborns and the frequency of congenital hearing loss was $1.7 \%$. According to our results, hyperbilirubinemia was more common in infants with hearing loss.

Conclusion: Performing hearing screening tests in all newborns, raising public awareness on this issue, and legal follow-up are very important.
\end{abstract}

Keywords: newborn, hearing loss, otoacoustic emission, auditory brainstem response.

DOI: 10.5798/dicletip.620486

Yazışma Adresi / Correspondence: SanemOkşanErkan, Department of Otorhinolaryngology, Head and Neck Surgery 33023 st., Adana, 01060, Turkey e-mail: sanemyilmaz67@yahoo.com 


\section{Çukurova Bölgesindeki Yenidoğan İșitme Testi Sonuçları}

\section{Öz}

Amaç: Çalışmamızın amacı Adana Şehir Eğitim ve Araştırma Hastanesinde yenidoğan bebeklerdeki işitme kaybı oranını araştırmaktır.

Yöntemler: Hastanemizde Kasım 2018 ile Şubat 2019 arasında 2022 yenidoğan işitme tarama testi yapılmıştır. İlk test olarak transient evoked otoacoustic emission (TEOAE), geçemeyenlere 2. aşamada tekrar transient evoked otoacoustic emission, geçemeyene ise üçüncü aşamada otomatik işitsel beyin sapı yanıtı(A-ABR) testi yapılarak, 3 aşamalı tarama protokolü uygulanmıștır. Bu iki testi geçemeyenlere ise klinik BERA testi uygulanmıștır. Risk faktörü olan bebekler belirlenmiştir.

Bulgular: 2022 yenidoğanın 34'ünde işitme kaybı mevcuttur ve konjenital işitme kaybı oranımız \%1,7'dir. Hiperbilüribinemi işitme kaybının daha sık saptanmasına neden olmaktadır.

Sonuç: İşitme tarama testlerinin tüm yeni doğanlarda yapılması gerekir. Bu konuda toplumun bilinçlendirilmesi ve yasal takip oldukça önemlidir.

Anahtar kelimeler: Yenidoğan, işitme kaybı, otoakustik emisyon, işitsel beyin sapı yanıtı.

\section{INTRODUCTION}

Hearing loss is a common condition that occurs in one newborn every 500-1000 births and it is seen more often than other congenital diseases $^{1}$. The frequency of hearing loss in healthy newborns ranges from 0.1 to $0.6 \%{ }^{2}$. Having normal hearing, especially during early infancy, affects the development of speech and language, social, emotional, and mental intelligence ${ }^{3}$.

The diagnosis age of hearing loss was made around 18-36 months before screening programs began. If the hearing loss was mild and moderate, diagnosis age increased even further. In this sense, hearing screening tests are very important for early diagnosis. If a child with moderate hearing loss of 35-40 dB does not use a hearing aid, they will miss $50 \%$ of speech $^{4}$. This causes impairment speech and language development in early childhood and poor success in the school period. By contrast, the language and speech development of children in the first 6-9 months of treatment is close to normal or normal 5 . This is why, with early diagnosis and early use of hearing aids, even with special hearing and speech rehabilitation, it is possible in our country for people to have normal healthy lives because of hearing screening in the follow-up of the Ministry of Health. The American Academy of Pediatrics Infant Hearing Committee also recommends screening for congenital hearing loss in the first month, verification in the first 3 months, and medical intervention in the first 6 months ${ }^{6}$. A society with individuals with hearing impairment is an undesirable situation in every country. This is why hearing screening programs have been launched all over the world. Hearing screening can detect half of these cases ${ }^{7}$.

Neonatal hearing screening is performed with transient evoked auto-acoustic emission (TEOAE) and automated auditory brainstem response (A-ABR). TEOAE is the acoustic echo response of hair cells of the inner ear to stimulus, which is measured from the outer ear pathway. The presence of the response indicates that there is no more than $40 \mathrm{~dB}$ hearing $\operatorname{loss}^{8}$. A-ABR is the electrical response of the brainstem auditory pathway and the auditory nerve to a click stimulus. Both are easy to use, practical, non-invasive, fast, and cost-effective investigations. However, TEOAE is affected by debris and serous otitis media, 
whereas A-ABR is not. Performing TEOAE is quick, A-ABR takes longer and requires technical skills ${ }^{9,10}$. There is also an obligation to use electrodes in A-ABR, and it must be performed while the newborn is asleep. TEOAE cannot detect retrocohlear pathologies and hearing loss less than $35 \mathrm{~dB}^{11}$. In both tests, the result is given as 'pass' or 'fail.' In further evaluation, brainstem evoked response audiometry (BERA) is used and based on the principle of evaluation of the response that the brainstem and auditory nerve give to electrical stimulus ${ }^{12}$.

In this article, we present a neonatal hearing screening protocol and test results in healthy neonates from Adana City Hospital.

\section{METHOD}

Two thousand twenty- two healthy newborns were evaluated in our hospital in terms of hearing and ethical approval was obtained from our Ethics committee (373/2019). Results between November 2018 and February 2019 were evaluated retrospectively. Scans were performed within 1 to 7 days of birth. Neonatal hearing loss and risk factors were evaluated according to the three-step protocol within the scope of the Ministry of Health screening program. Hearing screening was performed using TEOAE and A-ABR (Otometrics Madsen Accuscreen, Denmark). Newborns were first examined by an otorhinolaryngologist in terms of earwax or effusion in the ear that could affect the test. The risk factors for hearing loss and data about birth were investigated.

The test was performed in a purpose-designed room for scanning tests using the Quick Screen mode with $51 \mathrm{~dB}$ SPL noise and SNR at $\geq 3 \mathrm{~dB}$, because TEOAE is masked in the presence of excessive environmental noise. Periods in which newborns were calm or sleeping were preferred. Both ears were evaluated. A 'pass' response observed in the device meant that the newborn had passed the test and a 'refer' response meant that the newborn had failed the test.

A three-step protocol was applied in the hearing screening. In the first step, two-sided TEOAE was applied to the newborns. Getting a response from the newborn was considered as a 'pass.' Newborns with no response were called back 15 days later to repeat the test. Newborns who failed TEOAE for the second time were called back for to undergo an A-ABR test, which was evaluated using the same device and different headphones and electrodes.

Newborns who failed A-ABR were directed for clinic BERA which was performed during spontaneous sleep in a room where sound isolation was provided. Madsen ERA 2250 and TDH-39 type headphones were used for BERA. The vertex-mastoid configuration was applied and the resistances of the electrodes were kept lower than 5000 ohms.

As a stimulant, a sinusoidal click stimulus was given with a $0.5-\mathrm{ms}$ duration with alternating polarity. The stimulus rate was $30 / \mathrm{sec}$ and 2000 stimuli were averaged. The lowest value with which the fifth wave was obtained was determined as the threshold value and the findings were recorded. Newborns who failed BERA were taken to the rehabilitation program and amplification or implantation was planned.

The newborns' sex, delivery method, birth weight, and birth week were recorded. Risk factors within the family were discussed recorded in the first interview and processed into the computer system of the Ministry of Health. Risk factors such as febrile illness or toxoplasma, rubella, cytomegalovirus, herpes group infections (TORCH), consanguinity, family history of hearing loss, hyperbilirubinemia in the newborn, phototherapy, and history of intensive care unit (ICU) stay were all questioned. The results of the scans were saved in the follow-up book at 
our hospital and on the data screen of the Ministry of Health.

\section{RESULTS}

Of the 2022 infants included in the study, $49.9 \%$ were female and $50.1 \%$ were male. of the 2022 infants, 520 (25.7\%) did not pass the first test. Two hundred twenty-eight $(11.3 \%)$ of the 520 infants who were called back for second test did not pass. One hundred ninetytwo $(9.5 \%)$ of the 228 infants who were called back for third test did not pass. Thirty-four $(1.7 \%)$ of the 192 infants who underwent clinic BERA had severe or very severe hearing loss and were directed for rehabilitation. Four $(0.2 \%)$ infants had hearing loss on the right side, $2(0.1 \%)$ had hearing loss on the left side, and $28(1.4 \%)$ had bilateral hearing loss (Table 1).

Table 1: The number and percentage of newborns who failed the tests

\begin{tabular}{|c|c|c|c|c|c|}
\hline & \multirow{2}{*}{$\begin{array}{l}\text { The } \\
\text { number of } \\
\text { newborns } \\
\text { tested }\end{array}$} & \multicolumn{2}{|c|}{$\begin{array}{c}\text { The number of } \\
\text { newborns failed the } \\
\text { test } \mathrm{n}(\%)\end{array}$} & \multirow[b]{2}{*}{ Both sides } & \multirow[b]{2}{*}{ Total } \\
\hline & & Right & Left & & \\
\hline $\begin{array}{l}\text { First test } \\
\text { (TEOAE) }\end{array}$ & 2022 & $\begin{array}{c}108 \\
(5.3 \%)\end{array}$ & $\begin{array}{c}202 \\
(10.0 \%)\end{array}$ & $\begin{array}{c}210 \\
(10.4 \%)\end{array}$ & $\begin{array}{c}520 \\
(25.7 \%)\end{array}$ \\
\hline $\begin{array}{l}\text { Second } \\
\text { test } \\
\text { (TEOAE) }\end{array}$ & 520 & $\begin{array}{c}54 \\
(2.7 \%)\end{array}$ & $70(3.5 \%)$ & $\begin{array}{c}104 \\
(5.1 \%)\end{array}$ & $\begin{array}{c}228 \\
(11.3 \%)\end{array}$ \\
\hline $\begin{array}{l}\text { Third test } \\
\text { (A-ABR) }\end{array}$ & 228 & $\begin{array}{c}38 \\
(1.9 \%)\end{array}$ & $59(2.9 \%)$ & 95 (4.7\%) & 192 (9.5\%) \\
\hline $\begin{array}{l}\text { Fourth } \\
\text { test (C- } \\
\text { BERA) }\end{array}$ & 192 & $4(0.2 \%)$ & $2(0.1 \%)$ & $28(1.4 \%)$ & $34(1.7 \%)$ \\
\hline
\end{tabular}

Ten $(29.4 \%)$ infants who were born through vaginal delivery and 24 (70.6\%) who were born via cesarean delivery failed the tests. There was no statistically significant difference between infants born with vaginal or cesarean delivery in terms of hearing loss. Infants with hearing loss had more hyperbilirubinemia than infants without hearing loss $(\mathrm{p}<0.05)$ (Table 2).
Table 2: Relationship between hearing loss and risk factors

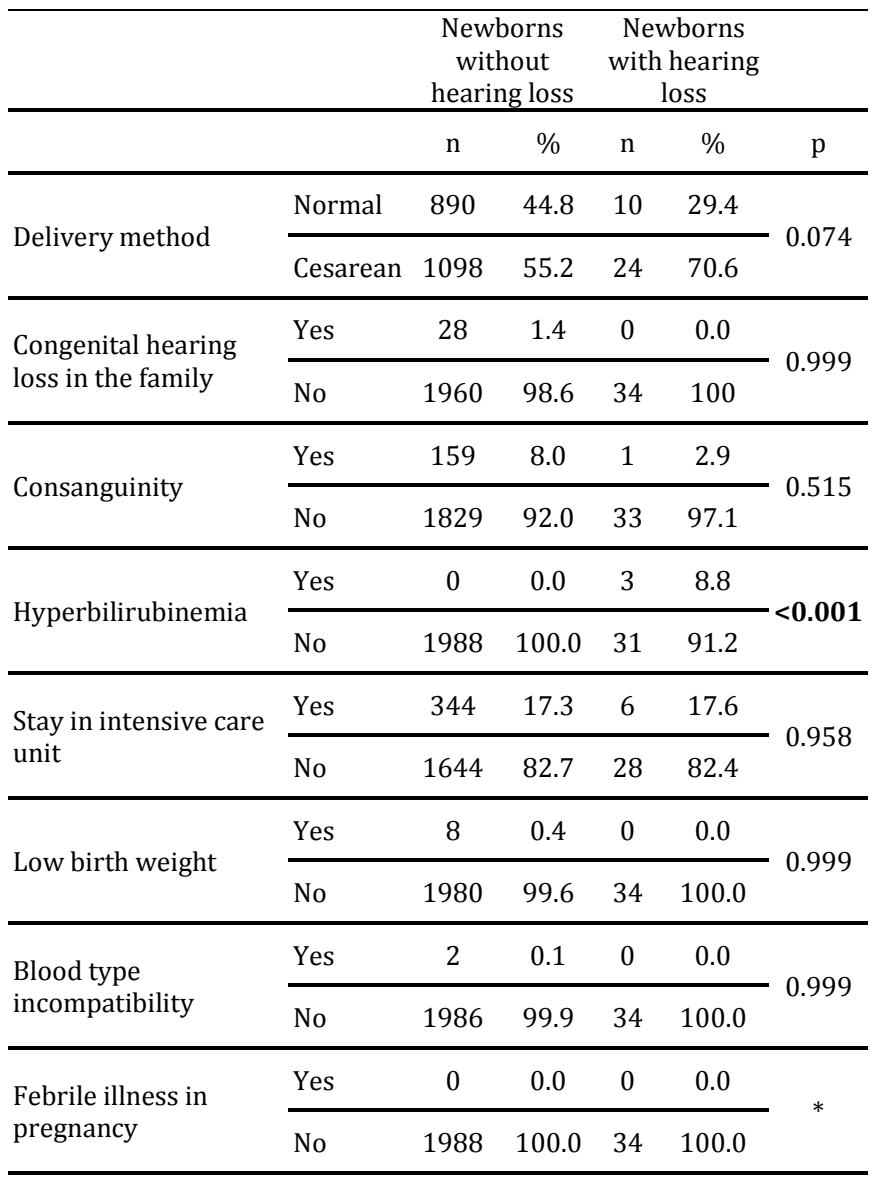

Clinic BERA was performed in 192 infants, detecting moderate or severe hearing loss in 34 infants. The features and risk factors of these infants are given in Table 3.

In total, of the 2022 infants included in the study, hearing loss was detected in 34 and the frequency of congenital hearing loss was $1.7 \%$.

\section{DISCUSSION}

National hearing screening programs began for the first time in 1993 in the United States. Today, it is performed in an increasing number of countries, especially England, Canada, India, Germany, and Australia. There are differences in application across these countries. In our country, screening began to be performed at Marmara University in 1994 and a screening 
project was started at 729 centers by the Ministry of Health ${ }^{13}$.

Table 3: Features of newborns with hearing loss

\begin{tabular}{|c|c|c|}
\hline & & $\mathrm{n} \quad \%$ \\
\hline \multirow{2}{*}{ Sex } & Female & 2058.8 \\
\hline & Male & 1441.2 \\
\hline \multirow{2}{*}{ Delivery method } & Normal & 1029.4 \\
\hline & Cesarean & 2470.6 \\
\hline \multirow{2}{*}{ Febrile illness in pregnancy } & Yes & $\begin{array}{ll}0 & 0.0\end{array}$ \\
\hline & No & 34100 \\
\hline \multirow{2}{*}{ Congenital hearing loss in the family } & Yes & $\begin{array}{ll}0 & 0.0\end{array}$ \\
\hline & No & 34100 \\
\hline \multirow{2}{*}{ Consanguinity } & Yes & 12.9 \\
\hline & No & 3397.1 \\
\hline \multirow{2}{*}{ Low birth weight } & Yes & $\begin{array}{ll}0 & 0.0\end{array}$ \\
\hline & No & 34100 \\
\hline \multirow{2}{*}{ Hyperbilirubinemia } & Yes & 38.8 \\
\hline & No & 3191.2 \\
\hline \multirow{2}{*}{ Stay in intensive care unit } & Yes & 617.6 \\
\hline & No & 2882.4 \\
\hline \multirow{2}{*}{ Blood type incompatibility } & Yes & $\begin{array}{ll}0 & 0.0\end{array}$ \\
\hline & No & 34100 \\
\hline Birth week (mean \pm SD) & \multicolumn{2}{|c|}{$37.59 \pm 2.19$} \\
\hline
\end{tabular}

In the international literature, congenital hearing loss rates range from $0.13 \%$ to $0.60 \%$. The rate was $1.7 \%$ in our study, the rates of unilateral and bilateral hearing loss were $0.3 \%$ and $1.4 \%$, respectively. In another study conducted in our country, the rates of unilateral and bilateral hearing loss were $0.17 \%$ and $0.3 \%$, respectively ${ }^{14}$.

It was shown that one-third of the cases with cochlear hearing loss passed the neonatal screening test ${ }^{15}$. Although risky infants pass screening, they should be subjected to an audiologic evaluation at least once between 24 and 30 months ${ }^{16}$. In children with risk factors for hearing loss, it is recommended to use the A-ABRtest, even if they pass TEOAE ${ }^{17}$.

In different countries, there are many different protocols in which TEOAE and A-ABR are used in newborn hearing screening programs. The most commonly used screening program for neonatal hearing screening is a 3-step screening program and this protocol includes performing TEOAE twice and then A-ABR once $^{18}$. In our study, both methods were used together because they gave information about different areas. First, the TEOAE + retest TEOAE + A-ABR were used in the screening, and clinic BERA was performed in the remaining infants. A-BERAis not practical because it requires experience and takes longer to perform which is why we use it as the third test.

According to the literature, hearing loss is expected in $0.1 \%$ of healthy newborns and in $10 \%$ of risky newborns ${ }^{19,20}$. There are some studies only performed in ICUs on risky newborns, not investigating healthy infants. However, our study covered all infants in our region. In our study, 6 of 34 infants with hearing loss had a history of stay in an ICU and no significant correlation was found between hearing loss and staying in anICU. Ifhearing screening was performed only in infants with risk factors, only half of the infants with hearing loss would be detected ${ }^{21}$. Hearing loss is also detected in healthy infants. In our study, no significant relationship between risk factors and hearing loss was found, except for hyperbilirubinemia. However, different studies have shown significant correlations between different risk factors and hearing loss. The most common risk factors are ototoxic treatments, prematurity, low birth weight, and ICU stay of more than 7 days $^{22}$. History of febrile illness of the mother in pregnancy and low birth weight were shown to be the most common risk factors of hearing loss ${ }^{23}$. 
The relationship between birth week and hearing loss has not been evaluated in studies from our country. In our study, birth week data were included for the first time. There was no difference between infants who failed and passed the tests in terms of mean birth week. The mean birth week did not differ significantly between infants who did and did not pass. The mean gestational age was 37.59 weeks in 34 infants who failed the tests and 38.02 weeks in 1980 infants who passed the tests ( $p>0.05$ ).

It has been reported in studies from our country and from around the world that there are newborns who cannot be followed up. In our hospital, there are also patients who do not continue follow-up protocols. Hearing screening tests are very important for social and psychological development; therefore, family physicians, pediatricians, and otorhinolaryngologists have important responsibilities in this regard. In addition, keeping records and questioning risk factors carefully by well-educated and experienced personnel will reduce the proportion of errors in data. Informing the family correctly and giving a detailed description as to why all tests to be done will reduce the deficiencies and patient loss during follow-up.

\section{CONCLUSION}

Hearing screening was performed in 2022 infants and $9.5 \%$ of them underwent clinic based BERA due to suspected hearing loss. As a result, hearing loss was detected in $1.7 \%$ of infants. According to our results, hyperbilirubinemia was more common in infants with hearing loss. Performing hearing screening tests in all newborns, raising public awareness on this issue, and legal follow-up are very important. Given thatour study had a small sample size, a larger number of patients must be studied to clearly determinenewborns with hearing loss.

Ethical Approval: All procedures performed in this study involving human participants were in accordance with the ethical standards of the institutional research committee and with the 1964 Helsinki Declaration and its later amendments comparable ethical standards. The study was approved by the institutional ethics committee. This article does not contain any studies with animals performed by any of the authors.

Conflict of interest: The authors declare that they have no conflict of interest.

Financial Disclosure: The authors declared that this study has received no financial support.

\section{REFERENCES}

1. Ohl C, Dornier L, Czajka C, et all. Newborn hearing screening on infants at risk. Int $J$ Pediatr Otorhinolaryngol 2009; 73: 1691-5.

2. Thompson DC, McPhillips H, Davis RL,et all. Universal newborn hearing screening: summary of evidence. JAMA 2001; 286: 2000-10.

3. Mazurek B, Winter E, Fuchs J, Haupt H, Gross J. Susceptibility of the hair cells of the newborn rat cochlea to hypoxia and ischemia. Hear Res 2003; 182: 2-8.

4. Genç GA, Başar F, Kayıkçı ME, ve ark. Hacettepe Üniversitesi yenidoğan işitme taraması bulguları. Çocuk Sağlığı ve Hastalıkları Dergisi 2005; 48: 11924.

5. Vohr B, Jodoin-Krauzyk J, Tucker R, et all. Early language outcomes of early identified infants with permanent hearing loss at 12 to 16 months of age. Pediatrics 2008; 122: 535-44.

6. American Academy of Pediatrics, Joint Committee on Infant Hearing. Year 2007 position statement: principles and guidelines for early hearing detection and intervention programs. Pediatrics 2007; 120:898-921.

7. Kennedy CR. Neonatal screening for hearing impairment. Arch Dis Child 2000; 83:377-82.

8. Collet L, Veuillet E, Berger-Vachon C, Morgon A. Evoked otoacoustic emissions: relative importance of age, sex and sensorineural hearing loss using a mathematical model of the audiogram. Int J Neurosci 1992; 62: 113-22. 
9. Joint Committee on Infant Hearing. 1994 Position Statement. Otolaryngol Head Neck Surg 1995; 113:191-6.

10. Sennaroğlu G, Akmese PP. Risk Factors for Hearing Loss and Results of Newborn Hearing Screening in Rural Area. Int Adv Otol 2011;7: 343-50.

11. Geal-Dor M, Adelman C, Levi H et all. Comparison of two hearing screening programs in the same population: oto-acoustic emissions (OAE) screening in newborns and behavioral screening when infants. Int J Pediatr Otorhinolaryngol 2010; 74:1351-5.

12. Doyle KJ, Burgraff B,Fujikava S, Kim J. Newborn hearing screening by otoacoustic emissions and automated auditory brain stem response. Int J Pediatr Otorhinolaryngol2001; 59: 23-8.

13. Hacettepe Üniversitesi Yenidoğan İşitme Taraması ve Erken Tanı Uygulama ve Araştırma Merkezi. http://www.yitmer.hacettepe.edu.tr/tarihce.shtml

14. Özbay İ, Kucur C, Oğhan F, et all. Newborn hearing results in an inner part of Aegean region. J Med Updates 2014; 4: 105-9.

15. Harlor AD Jr, Bower C. Hearing assessment in infants and children: recommendations beyond neonatal screening. Pediatrics 2009; 124: 1252-63.

16. Gökçay G, Kılıç A, Devecioğlu E. Taramalar, işitmenin değerlendirilmesi. İçinde: Devecioğlu Ö, Clitak A (ed). Pediyatride Rutinler (3. Baskı). İstanbul: İstanbul Tıp Kitabevi, 2014: 127-8.
17. Vohr B, Simon P, McDermott C, et all. Early hearing screening, detection and intervention (EHDI) in Rhode Island. Med Health RI 2002; 85: 369-72.

18. Jakubikova J, Kabatova Z, Zavodna M. Identification of hearing loss in newborns by transient otoacoustic emissions. Int J Pediatr Otorhinolaryngol 2003 ; 67:15-8.

19. Eryılmaz A, İleri Ö, Çakın M, Saraydaroğlu G, Hızalan İ, Onart S. Uludağ Üniversitesi Yenidoğan İşitme Taraması Sonuçları. Uludağ Üniversitesi Tıp Fakültesi Dergisi2009; 35: 27-9.

20. Martin WH, Schwegler JW, Gleeson AL, Shi YB. New techniques of hearing assessment. Otolaryngol Clin North Am 1994;27:487-510.

21. American Academy of Pediatrics. Task Force on Newborn and Infant Hearing. Newborn and infant hearing loss: detection and intervention. Pediatrics 1999;103:527-30.

22. Bielecki I, Horbulewicz A, Wolan T. Risk factors associated with hearing loss in infants:an analysis of 5282 referred neonates. Int J Pediatr Otorhinolaryngol 2011; 75: 925-30.

23. Karaca ÇT, Toros SZ, Naiboğlu B, Verim A, Çelebi Ş. Yenidoğan İşitme Taraması Sonuçlarımız. Van Tıp Dergisi 2014;21:67-71. 